\title{
Relaciones entre escritores gallegos y brasileños en el exilio español: el testimonio de Lorenzo Varela y Newton Freitas
}

\author{
María Victoria NAVAS SÁNCHEZ-ÉLEZ \\ UCM \\ mvnavas@filol.ucm.es
}

\begin{abstract}
Resumen: Este estudio recorre la vida y obra de Lorenzo Varela (1916-1978) con la intención de encontrar los vínculos que posibilitaron su encuentro con artistas brasileños. Con este propósito se han rastreado las revistas españolas —P.A.N., El Mono Azul, Hora de España y Ahora—; y las extranjeras —Romance (Méjico), De Mar a Mar y Correo Literario (Buenos Aires)-. Se hace un repaso a las ocasiones en las que hay huella del interés de Lorenzo Varela por la vida cultural brasileña y se concluye que, ésta surge esencialmente a partir de su etapa vital atlántica, y que se manifiesta con más intensidad en los intelectuales Newton Freitas y Lídia Besouchet.
\end{abstract}

Palabras clave: Lorenzo Varela, Newton Freitas, Lídia Besouchet, exilio español en América del Sur, literatura gallega.

\begin{abstract}
This study goes through Lorenzo Varela's life and work (19161978) trying to find the links that made possible his meeting with Brazilian artists. With this intention, we revised the Spanish magazines -P.A.N., El Mono Azul, Hora de España and Ahora-; and the foreign ones-Romance (Mexico), De Mar a Mar and Correo Literario (Buenos Aires)-. A revision is required whenever there are traces of Lorenzo Varela's interest in the Brazilian cultural life, yet and it is concluded that this interest emerges essentially from his Atlantic vital stage, which becomes more apparent in Newton Freitas and Lídia Besouchet' cases.
\end{abstract}

Key-words: Lorenzo Varela, Newton Freitas, Lídia Besouchet, Spanish exile in South America, Galician exile.

En el año 2005, con motivo del Día das Letras Galegas, dedicado al escritor Lorenzo Varela, se elaboraron muchos trabajos sobre su vida y su obra. Sin embargo hay un aspecto que, en mi opinión, no ha sido desarrollado, con la debida atención. Se trata $-\mathrm{y}$ creo que la oportunidad de que el VIII Congreso Internacional de Estudos Galegos se celebrase en Bahía lo mere- 
ce ${ }^{1}$ - se trata, digo, de su relación con los intelectuales brasileños. Basándome en los textos conocidos del autor gallego: las revistas que dirigió, o en las que participó, en España y América, y los libros que tradujo, mi intención es hacer un inventario de las ocasiones en que el mundo brasileño está presente en su producción. Para ello he vaciado, además de las revistas españolas en las que colaboró, las revistas publicadas en Méjico, Romance, y en Buenos Aires, De Mar a Mar y Correo Literario, para llegar a la conclusión de que no son pocas las ocasiones en las que la presencia brasileña aparece destacada.

\section{LORENZO VARELA (LA HABANA, 1916 - MADRID, 1978)}

Lorenzo Varela, nombre artístico con el que se conoce a Xesús Manuel Lorenzo Varela Vázquez - sinónimo para algunos (Alonso Montero, 1977), para otros (Quintá García, 2005: 9-10) abreviatura de su nombre- nació en el barco «La Navarre» (Salgado, 1995: 17), camino de la emigración hacia La Habana el 10 de agosto de 1916. Aunque sus padres eran originarios del concejo de Monterroso en Lugo ${ }^{2}$, vivió su primera infancia en La Habana y en Buenos Aires, pasó a su adolescencia en Lugo y su juventud en Madrid. Después, en su madurez, se exilió primero a Montevideo, luego a Méjico y después a Buenos Aires, para, finalmente, regresar a Madrid en 1976, donde falleció después de 35 años de involuntario alejamiento ${ }^{3}$. Durante su adolescencia en Lugo, L. Varela ya mostraba inquietudes intelectuales y políticas, junto a sus amigos Ánxel Fole y Ramón Piñeiro, 'Os tres irmáns' del poema ${ }^{4}$, pues le vemos ocupando un lugar destacado en la organización de las Mocedades Galeguistas, al mismo tiempo que militaba en el troskismo (F. Salgado, 2005a: 30).

\section{LORENZO VARELA EN EL MADRID REPUBLICANO}

En 1934, con dieciocho años, nuestro autor se dirige a Madrid para cursar la carrera de Filosofía y Letras. Allí conocerá, entre otros a Neruda, a Miguel Hernández, a Valle-Inclán, y a los miembros de la generación del 27, y frecuentará a intelectuales gallegos como los hermanos Dieste, Otero Espasandín, por citar algunos. En la capital tendrá su bautismo como crítico ${ }^{5}$ en la revista

1 Texto leído en dicho Congreso dedicado a «Galicia do outro lado do Atlántico: voces reunidas na Bahía», celebrado entre los días 12 al 15 de septiembre de 2006 en Salvador de Bahía y organizado por la Asociación Internacional de Estudos Galegos.

2 Para más información vid, por ejemplo, Lopo (2005: 102-103).

${ }^{3}$ Un buen resumen de su vida y obra se puede ver en Axeitos (ed.) (2000: 7-34) o en F. Salgado (2005a:). Otros estudiosos del autor son, entre otros, Ferreiro Fente y Alonso Montero. Puede consultarse también el reciente repertorio bibliográfico sobre Lorenzo Varela de García López (2009).

${ }^{4}$ Escrito en 1940 e inédito hasta 1945. Existe otro versión hecha por Seoane en 1979a. Vid a este respecto Ferreiro Fente (1997: 83 y ss.) y García López (2005: 119-124).

5 Algunos autores refieren que probablemente Lorenzo Varela en su época gallega pudiera haber publicado algún poema en la revista Resol, que dirigía Arturo Cuadrado en Santiago de Com- 
P.A.N. (Poetas, andantes e navegantes) (1935) (Axeitos, 2001: 75). Al año siguiente iniciará sus colaboraciones en el periódico madrileño El Sol, (F. Salgado, 2005a: 62 y 69-72). También durante su estancia en Madrid participará en las Misiones Pedagógicas y asistirá a varias tertulias, como las del Café Pombo o la Granja del Henar (Ferreiro Fente, 2005: 37).

\section{LORENZO VARELA Y LA GUERRA CIVIL ESPAÑOLA}

Durante la Guerra Civil española, afiliado al Partido Comunista y distanciado del troskismo, la firma del escritor estará presente en numerosas publicaciones de la zona republicana (Ferreiro Fente, 2005: 44 y ss.). Son textos ${ }^{6}$ que hablan en castellano de batallas y héroes de la resistencia, de las brigadas internacionales: 'Romance de Fernando de la Rosa' (Bernárdez, 2005: 79-80), publicados en El Mono Azul (1936-1939) (F. Salgado, 2005a: 105); «Contra viento y marea. De la disconformidad a la comodidad y otras cosas», en Hora de España (1937-1938); «Literatura de guerra» en Ahora. Diario de la Juventud (Rodríguez Fer, 1999: 1324). Sin embargo, a partir de 1937 el escritor va a abandonar su actividad literaria para centrarse en su tarea política y militar (Ferreiro Fente, 205: 54). Después de leer sus textos de guerra (Rodríguez Fer, 1999: 1325 y ss.) podemos concluir, para el asunto que nos interesa - las relaciones entre L. Varela y los intelectuales brasileños-, que en esta primera etapa de la vida del escritor, 1934 a 1939, si existió una posible preocupación, o relación, con el mundo brasileño no ha quedado constancia de ello. Tras la caída de Cataluña, en 1939, Lorenzo Varela atraviesa la frontera francesa y es conducido al campo de refugiados de Saint Cyprien ${ }^{7}$ (F. Salgado, 2005a: 120), donde permanecerá hasta que se le proporcione su partida a Méjico (Bernárdez, 2005: 33).

\section{EL EXILIO (1939-1976)}

\subsection{El exilio en Méjico (1939-1942)}

En mayo de 1939 el autor parte (F. Salgado, 2005a: 130) en el barco Sinaia hacia Veracruz. Allí le esperan en el puerto, entre otros, León Felipe y Octavio Paz. Este último le introducirá en los medios intelectuales mejicanos y le ofrecerá la posibilidad de escribir en la revista Taller. (1939-1941).

Romance (1940 - 1941)

Durante los dos años que vivió en Méjico, el autor participó en importantes iniciativas culturales; la más significativa tal vez sea la creación de la revista

postela, y también en la Revista Yunque, dirigida por Ánxel Fole. Vid a este respecto F. Salgado (2005a: 36).

${ }^{6}$ Vid a este respecto Ferreiro Fente (1999: 533).

7 Para más información sobre los campos de concentración en Francia en que pudo estar Lorenzo Varela vid F. Salgado (1995: 118, n. 10). 
Romance. Revista Popular Hispanoamericana (1940-1941), de la que fue codirector, junto con Sánchez Barbudo (Bernárdez, 2005: 33). En Méjico se empieza a ampliar el horizonte temático del autor al proponerse que la revista $R o-$ mance tenga un carácter popular, que abarque temas de historia, arte, literatura, física, derecho, filosofía, etc.- y que esté abierta a todos los países americanos. Es aquí donde aparece por primera vez el término Brasil en los textos o iniciativas editoriales de nuestro escritor. Así el modelo que habían seguido los intelectuales españoles exiliados cuando crearon revistas al otro lado del Atlántico, la Revista de Occidente, de José Ortega y Gasset y Cruz y Raya de José Bergamín, se ve alterado con la propuesta innovadora de incorporar entre sus objetivos, en palabras de Lorenzo Varela (1979): «la América de habla española, y hasta donde hemos podido la de habla portuguesa, fueron incorporadas, es decir, pasaron a ser un mismo cuerpo, con nuestra tradición viva y con una misma "nostalgia de futuro común"» (pág. VI). Si bien es cierto que las colaboraciones propiamente dichas de intelectuales brasileños en la revista Romance no existen sí aparece en ella, desde el primer número, la cultura brasileña. Así vemos noticias sobre el éxito en París del ballet Jurupary; la representación de la ópera Ponaim de Víctor Neves, en Río Grande del Sur; y la cátedra de música que ha conseguido, en la Universidad de Río de Janeiro, el bibliotecario del Instituto Nacional de Música ${ }^{8}$. El número 2, en «Libros y Revistas. Brasil», da cuenta de las publicaciones de Sílvia Guaspari y de Énio de Freitas e Castro9. En «Revistas de Revistas. Brasil» se mencionan las de Ciências e Letras y Seiva ${ }^{10}$. En el mismo número se informa de la ciudad brasileña en la que se vende Romance ${ }^{11}$, información que vuelve a repetirse en el número siguiente, en la misma página. El número 3 en «La situación de algunos intelectuales» da cuenta del centenario de Machado de Assis ${ }^{12}$, cuya obra Dom Casmurro, se ha traducido al francés. En «Bibliografía» se anuncia un total de trece libros, originales o traducciones, publicados en Brasil. En algunos incluso se añade una pequeña información explicativa, probablemente gracias a Lorenzo Varela, pues era el responsable de ese apartado (Pérez Rodríguez, 2005: 51) ${ }^{13}$. «Revistas de Revistas» del número 4 , anuncia la publicación mensual de la italo-brasileña ${ }^{14} \mathrm{Au}$ gusta. Hasta el número 10 — «Revistas de Revistas»-, no volvemos a encontrar otras menciones brasileñas pero se anuncia con un cierto detenimiento la

8 Año I, n. ${ }^{\circ} 1,1940: 15$.

9 Año I, n. ${ }^{\circ}$ 2: 15.

${ }^{10}$ Las transcripciones de autores y títulos presentan varias erratas que tratamos de subsanar. Año I, n. ${ }^{\circ} 2: 22$.

11 Año I, n. ${ }^{\circ} 2: 23$.

12 Año I, n. ${ }^{\circ}$ 3: 20.

${ }^{13}$ Reynaldo Moura: Noite de Chuva. Cyro Martins: Enquanto as aguas correm. Emil Ludwig: Memorias de um caçador de homens (Trad. de Mario Quintana). H. W. Van Loon: As Artes. Trad. de Mário Guaspari. Darcy Azambuja: A prodigiosa aventura. José Conrad: Lord Jim. Trad. de Mário Quintana. Souza Junior: Enquanto a morte não vem. Memorias do Conselheiro Francisco da Silva (O Chalaca). Marqués Rebelo: A estrela sobe. Raquel de Queiroz: As tres Marias. Telmo Vergara: Estrada perdida. Octavio de Faria: Tragedia burguesa; II Os caminhos da vida. Tristão de Athayde: Contribuicão a história do modernismo: o premodernismo». Romance, Año, I, n. ${ }^{\circ}$ 3: 22.

${ }^{14}$ Año I, n. ${ }^{\circ} 4: 22$. 
revista Diretrizes ${ }^{15}$. «Últimas ediciones y noticias», del número 11 (pág. 20), informa de la llegada de Gabriela Mistral a Brasil y de la traducción que está llevando a cabo Jorge Amado de Doña Bárbara. Termina la columna con «Nuevas ediciones de libros brasileños» ${ }^{16}$ como la de Jorge Amado, A. B. C. de Castro Alves.

Se produce un salto informativo. En el número 14, «Bibliografía» presenta una breve noticia sobre un texto de Carlos Alberto Clulow ${ }^{17}$, y «Revistas de Revistas» anuncia Revista das Academias das Letras y Augusta. «Biografía» inserta la publicación de Zaratrusta Morreu, editado en São Paulo ${ }^{18}$. El número 16, último en que participó Lorenzo Varela por desavenencias con los editores, en «Revista de Revistas», incluye la noticia de Revista das Academias de Letras y Belas Artes ${ }^{19}$. El número 18, «Últimas ediciones y noticias», informa de la llegada de profesores brasileños a Montevideo para impartir unos $\operatorname{cursos}^{20} \mathrm{y} \ll \mathrm{Bi}$ bliografía» menciona un libro de Melo Jorge sobre Eça de Queiroz ${ }^{21}$. En esta última sección, el número 19 inserta diecisiete títulos editados en Brasil - originales o traducidos-, algunos ya publicitados en números anteriores, que van desde la pedagogía a la historia y a la crítica ${ }^{22}$. El número 20 , «Libros recibidos», refiere la traducción de Mar muerto ${ }^{23}$ de Jorge Amado, y una serie de revistas en la sección correspondiente ${ }^{24}$. «Bibliografía» del número 22 referencia la publicación de Ivan Lins sobre Ruiz de Alarcón ${ }^{25}$, y «Revistas de Revistas» da cuenta de Seiva, Terra Imatura, Aspectos, Ciências e Letras, Augusta y Estudos (pág. 23). El número siguiente, el 23, y en la misma sección, indica las revistas Estudos y Aspectos (pág. 23). Braulio Sánchez-Sáez escribe en el último número de la revista, el 24, un artículo largo sobre el panorama editorial brasileño y sus publicaciones en la sección «Últimas ediciones y noticias. Literatura del Brasil. Hombres y libros del pasado año» ${ }^{26}$, con referencias a publicaciones de, entre otros autores, Drummond de Andrade, José de Alencar o Jorge Amado; en «Bibliografía», hay información sobre textos de literatura, derecho y política ${ }^{27}$; y en la de «Revistas de Revistas» la publicación del número 24 de Aspectos (pág. 23). A partir del número 17, tal vez no se deba atribuir esta información a Lorenzo Varela, visto que éste ya no tenía responsabilidad en la revista, a no ser que, se pueda aceptar como premisa que los encargados de los números siguientes «pudieron usar el material acumulado por nosotros, o el que estaba en

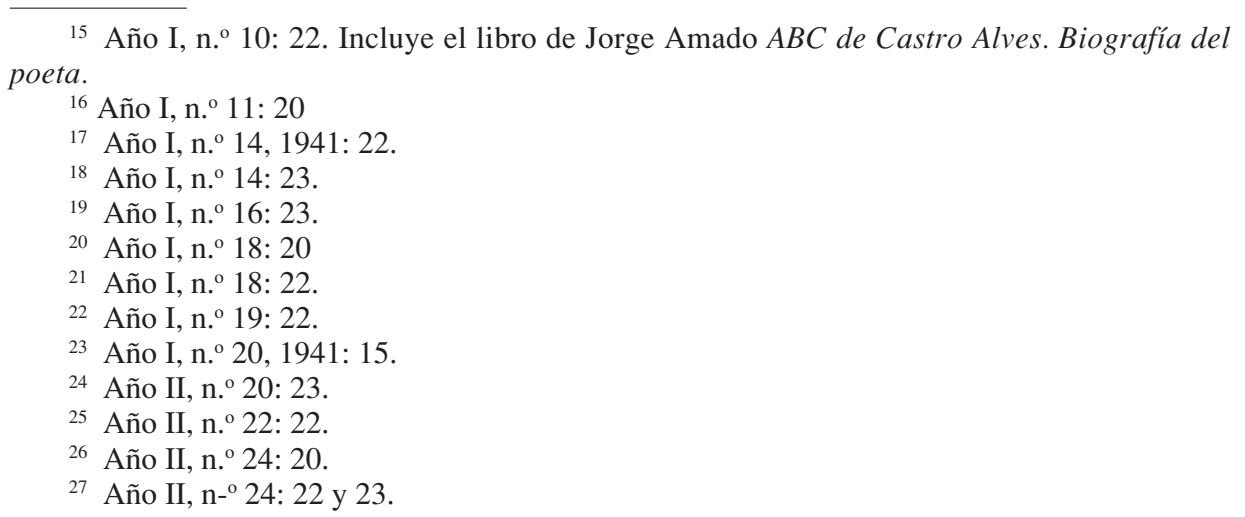


camino» (Sánchez Barbudo,1974: 4). La salida de L. Varela de la revista Romance será un duro golpe para el escritor y, en parte, el motivo por el que decidirá marchar a Argentina (F. Salgado, 2005a: 174). Pero durante la etapa mejicana L. Varela dejó muestras de una gran vitalidad cultural en sus colaboraciones en periódicos - El Nacional y El Popular (Salgado et alii, 2005: 20)—, en revistas Letras de Méjico (Ferreiro Fente, 2005: 72) - y en la publicación de su primer libro de poemas en castellano, Elegías españolas, en 1940 (Bernárdez, 2005: 36-39).

\subsection{El exilio en Argentina (1942-1947)}

Llega nuestro autor a principios ${ }^{28} \mathrm{de} 1942$, a Buenos Aires con intención de instalarse en la ciudad donde residía su padre. Arturo Cuadrado, Rafael Dieste, amigos desde los días anteriores a la Guerra Civil, su padre y Luís Seoane, le esperan en el puerto (Ferreiro Fente, 2005:72).

\section{El café Tortoni}

En cuanto se asienta L. Varela en Buenos Aires sus amigos le hacen sitio en el café Tortoni. El Tortoni ${ }^{29}$ es un lugar de encuentro de emigrantes y de exiliados, hombres de artes, letras y pensamiento, que, procedentes de diferentes culturas, se identifican con los maltratados del mundo, y creen en la capacidad del hombre para cambiar el rumbo de la historia (F. Salgado, 2005a: 180). Frecuentaban este café, entre otros, Luís Seoane, Otero Espasandín, Rafael Dieste, Ramón de Valenzuela, Alberti, Guillermo de Torre. Pero además asistían intelectuales europeos y americanos como el pintor italiano Attilio Rossi ${ }^{30} \mathrm{o}$ el brasileño Newton Freitas (F. Salgado, 2005a:180 y n. 6). Newton de Freitas Coutinho (Vitória 1909-Río de Janeiro 1996), dramaturgo, ensayista, novelista y periodista (D. Salgado, 2005: 142), que trabajó en el Ministerio de Asuntos Exteriores de Brasil y fue agregado cultural en Bélgica, Inglaterra, Méjico, Argelia, Francia y España, además de director de la Agencia Nacional y divulgador de la cultura brasileña ${ }^{31}$, debe haber conocido a L. Varela en dicho café. De esta

${ }^{28}$ Algunos críticos retrotraen la fecha a diciembre de 1941, por ejemplo, Bernárdez (2005: 43).

${ }^{29}$ El establecimiento, situado en la Avenida de Mayo, n. ${ }^{\circ} 829$, había sido fundado en 1858, y era lugar de tertulias; en ellas participaron García Lorca, Pirandello, Gardel, Borges, Alfonsina Storni, Benavente, y un largo etcétera.

${ }^{30}$ Véase la relación en Seoane (ed.) (1979: 11). Vid también X. Alonso Montero (1994), o F. Salgado (2005: 180 y n. 6). Con todo, conviene recordar que las relaciones que existían entre artistas y escritores argentinos y brasileños se venían desarrollando por lo menos desde los años 20 , como se puede ver, por ejemplo, en las revistas vanguardistas Martín Fierro de Argentina y Festa de Brasil (Alcalá, 1990).

${ }^{31}$ He aquí algunos títulos: (1936): O genial Rebouças. Teatro. (1937): Porão. Novela. (1939): Diez escritores de Brasil. Con Lídia Besouchet. Buenos Aires. (1942): Brasil-Argentina: Breve esbozo histórico-comercial. Buenos Aires. Colección Problemas Americanos, dirigida por Newton Freitas. 
convivencia en el Tortoni nos habla el propio N. Freitas cuando escribe en el $R e$ quiem por Seoane, en 1979:

yo me sentía en casa. La simpatía brotaba espontánea como si se tratase de hermanos en lengua y cultura (pág. 97).

[Seonae] conseguía canalizar las cualidades de los demás por la sencilla razón de que él mismo era capaz de realizar aquello que los demás le exigían. Así, Lorenzo Varela (jah, Varela!), Arturo Cuadrado, Rafael Dieste, Isaac Díaz Pardo (...) Luis Baudizzone (...) aceptaban participar en el esfuerzo titánico que desenvolvía Seoane. (...) Me enorgullece haber participado de ese esfuerzo febril, de esa época inquieta e irrepetible (pág. 98).

Dice Seoane (1979: 11) del grupo del Tortoni, en referencia a Lorenzo Varela, Newton Freitas y la lengua portuguesa:

Por vegades facíanos compañía (...) o escritor brasileiro Newton Freitas. No grupo ese inicial de galegos: Dieste, Otero Espasandín, Colmeiro, Baltar, Varela...., considerábamonos todos como irmáns (...). Éramos irmáns verdadeiros. (...) Soñamos con editoriales que nunca, a pesar da nosa esperencia, poderíamos facer en calquer cidade de Galicia, imprimindo en idiomas galego, castelán e portugués.

Poca información más he podido recoger sobre la biografía de Newton Freitas. Por el texto referido deducimos que es demócrata, liberal izquierdista, revolucionario (de hecho se refugió, en 1935, por razones políticas en la casa del antifascista Battisteli, exiliado en Brasil). No sólo encontramos en Buenos Aires relaciones de L. Varela con el escritor N. Freitas sino también con el pintor, naturalizado brasileño, Carybé, o con Jorge Amado, del que L. Varela tradujo dos novelas. A Carybé lo conoció nuestro escritor, probablemente, durante su estancia en Argentina; por ejemplo, sabemos que ambos colaboraron en el periódico La Nación (Furrer, 1989: 434). A Carybé dedica L. Varela el poema «Versos de ciego para un pintor sonoro», en $1949^{32}$ (Furrer, 1989: 66). Y que dicho pintor vendió dos cuadros por intermedio de Lorenzo Varela y de Arturo Cuadrado. Esta amistad, como se ha dicho, viene ampliada a Jorge Amado. En carta que Carybé escribió, en 1967, desde Bahía, a L. Varela le anuncia su viaje a Sevilla, y finaliza ésta con recuerdos del novelista citado (F. Salgado, 2005a: 305 , n. 17) $)^{33}$. Además Carybé ${ }^{34}$ tradujo, en 1945, al español (y también ilustró), Macunaíma de Mário de Andrade (Furrer (ed.), 1989: 434), con el consejo de Newton Freitas y la colaboración de Lorenzo Varela, según comenta Lídia Besouchet (1989: 61). La obra de autores brasileños tuvo cabida en las revistas que

32 Seoane (ed.) (1979). También in Furrer (ed.) (1989).

${ }_{33}$ Los contactos del pintor con el mundo gallego deben haber seguido a lo largo de los años pues presentó una exposición en la Casa de Galicia de Madrid en 1996.

${ }^{34}$ Pero los vínculos de Carybé con los intelectuales gallegos residentes en Buenos Aires no se circunscriben sólo a L. Varela pues ilustró, por ejemplo, el artículo de Luís Seonae, «El terror fascista», publicado en el periódico Crítica (3-XI-1936) (Axeitos, 2003: 138). 
fundan los gallegos que vivían en el exilio americano. Pero también sucedió lo contrario. Por ejemplo, en lo que se refiere a Lorenzo Varela sabemos que hubo una reseña de Catro poemas galegos en O Jornal de São Paulo y de Lonxe por Lídia Besouchet, en 1944 (Callón, 2005: 75) (después reproducida en 1959 en Galicia emigrante) $^{35}$. L. Varela a través de la lengua gallega llegó al portugués y a la literatura brasileña, de que la que «acabou sendo un experto» (F. Salgado,

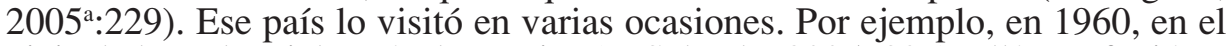
viaje de luna de miel a Río de Janeiro (F. Salgado, 2005: 287); allí se refugió en la segunda presidencia de Perón (idem, pág. 105); y también antes de volver definitivamente a Madrid, como se lee en carta que escribe a su mujer Marisa Gerstein (Salgado (ed.) (2005: 87).

Volviendo a la relación que existió entre Lorenzo Varela y Newton de Freitas hemos de decir que la amistad entre ambos se mantendrá hasta el final de sus días, según la documentación que hasta ahora conocemos ${ }^{36}$. Así cuando, en 1941, llega el escritor gallego a Argentina se sabe que, desde 1939, ya está viviendo allí el brasileño, según escrito de este último (1944: 1): «Entre o ano 1939 e o de 1944 mais de cem vezes discuti com Reinaudi diversos pontos de vista: por coincidência, talvez de sermos os dois provincianos ou recém chegados a Buenos Aires». Son varias las editoriales que fueron surgiendo de manos de estos exiliados gallegos en Argentina y en las que colaboró de diversas maneras L. Varela ${ }^{37}$. En el discurso de ingreso en la Real Academia Galega, Xosé Neira Vilas (2001: 23) da cuenta de las editoriales Emecé Editores (1939-1943), donde Newton Freitas publica en 1943, Los Braganza, y en 1947, la novela traducida El mestizo. Esta editorial tiene, además, varias colecciones, en una de ellas, «Buen Aire», publicará el brasileño, en 1942, Alôs Afro-Brasileños, edición a cargo de Luis M. Baudizzone, Arturo Cuadrado y Luís Seone. Inmediatamente después, en 1943, se crea la Editorial Nova, dirigida por Luís Seoane y Arturo Cuadrado, con diversas colecciones. En «Tierra Firme» saldrá a la luz Don Casmurro de Machado de Assis. En «Mar Dulce» se publicará en 1943, Amazonia: Leyendas Ñangatú, seleccionadas por N. Freitas; y en 1944, del mismo El 'Aleijadinho' de Antonio Francisco Lisboa; en 1946, Garibaldi en América de N. Freitas. En la colección «Biblioteca Histórica» se edita, en 1945,

35 Sería necesario también revisar la prensa de la época en Brasil para localizar otros casos de difusión de autores gallegos en dicho país. Por ejemplo, Salazar Bondy firma un artículo «Essência Humana de César Vallejo» (págs. 212 y ss.). Además hay que recordar que algunos escritores gallegos vivieron en Brasil como Álvaro das Casas (Alonso Montero, 1995: 95) (Rodríguez Fer (1994: 194-195) lo que no es de extrañar porque, según documentación recogida por Soutelo Vázquez (1998: 99 y 106, n. 14), la emigración gallega a Brasil fue la más importante después de la de Cuba y Argentina.

${ }^{36}$ Fernando Stornik, hijo de Marika, su mujer, tiene en su poder la correspondencia de los dos escritores. Su consulta puede darnos noticias de cómo se desarrolló su amistad en el interregno que va desde 1945, fecha de salida del brasileño de Argentina, hasta 1976, fecha del reencuentro en Madrid. Tal vez, cuando se publique la correspondencia de Mário de Andrade y Newton Freitas se puedan tener informaciones colaterales de la relación entre el escritor gallego y el intelectual portugués (Antelo, en prensa).

${ }^{37}$ Se mencionan ahora como base para argumentar las estrechas relaciones que existieron entre Seoane, Cuadrado, Varela y los intelectuales brasileños. 
Viajes y cautiverio entre los caníbales, de Hans Staden, traducido del portugués. En 1947, comienza su labor la Editorial Botella al Mar, dirigida por Arturo Cuadrado y Luis Seoane. Al año siguiente, publican de N. Freitas, Flávio de Carvalho ${ }^{38}$; en la colección, «La sirena escondida»; en 1949, Jaburuna: Cuentos y relatos del mismo; y en 1953, de Drummond de Andrade, Dos poemas (Neira, 2001: 23). Además Carybé, en 1948, escribe e ilustra Ajtuss en esta misma editorial, con prólogo de N. Freitas, «Dedicado a Mário de Andrade que corre agora nos vastos campos do céu» (Furrer (ed.) 1989: 435). La editorial Atlántida había sacado a la luz, en 1941, con dibujos de Castelao, Los sertones de Euclides da Cunha. Allí Lorenzo Varela traduce y prologa, en 1943, los Cantos y leyendas brasileñas de, entre otros, su amigo brasileño, libro que reseñará Luís Seoane, para la editorial Poseidón. En 1942, nuestro escritor había empezado a colaborar en la revista Sur (1931-1970), donde publica la reseña de Vaga música de Cecília Meireles (Pérez Rodríguez, 2005: 468-469), y, en castellano, su propio poemario Torres de amor $^{39}$ (Salgado, 2005:185).

De Mar a Mar (1942-1943)

La primera mención explícita de la relación literaria entre el brasileño y Lorenzo Varela surge en la revista De Mar a Mar. En esta publicación, de la que es codirector y cosecretario L. Varela, éste nos habla, en el momento de la edición facsímile de la misma en 1979, de la importancia que en el propósito editorial tuvo Newton Freitas:

Intentar simbólicamente el logro de cierta comunicación o diálogo entre las playas de América y de España (...). Fui yo mismo quien propuso el título a los demás amigos, tanto argentinos como españoles, más un italiano, el pintor y diseñador gráfico - Attilio Rossi-, que fue decisivo para la empresa, y un brasileño - Newton Freitas—, en el que se encarnaban, personalísimamente, los ritmos que podían expresar algo que por entonces fue bautizado risueñamente como una civilización afroeurogalaicoamericana (apud F. Salgado, 2005a: 186).

De Mar a Mar (1942-1943), es la primera de las tres grandes revistas que L. Varela va a codirigir en Argentina con Arturo Serrano Plaja ${ }^{40}$. El espíritu que abarcaba la cultura de ambos lados del atlántico, surge en el prólogo de la revista. Dice L. Varela en 1979:

Intentaba dar cauce y corriente viva a la voluntad (...) del mundo del espíritu esparcido en esa parcela (...) del universo humano que llamamos 'lo iberoa-

\footnotetext{
${ }^{38}$ Es el mismo texto que se encuentra editado en Cultura, Año I, n. ${ }^{\circ}$ 2: 267-269.

39 Este libro, próximo a la generación del 27 , se ciñe a las vivencias de la Guerra Civil y a la nostalgia por la lejanía de su tierra (Bernárdez, 2005: 47-48).

${ }^{40}$ Fundada por Lorenzo Varela, José Otero Espasandín y Arturo Serrano Plaja, con formato semejante al de Hora de España.
} 
mericano', un claro misterio que tiene por costado atlántico a Portugal y Galicia, en Europa, y por amplio pecho saliente, también sobre el Atlántico a Brasil, en América (pág. V).

Continúa el autor en el mismo sentido:

De Mar a Mar como Romance (...) representó un momento (...), en que, (...) se estableció a través de los mares, un puente firme, de verdad común, (...) entre los pueblos de la América de habla española y España. (Con un modesto intento de inclusión en la misma área, de la América de habla portuguesa) (págs. VIII-IX).

Lo cierto es que si el prólogo surge lleno de espectativas interculturales hispano-brasileñas la consulta al interior de los únicos siete números que salieron a la calle, puede conducir a cierta decepción. Pero si analizamos con cuidado el contenido de los números constataremos un total de aportaciones razonables. La presencia brasileña viene esencialmente destacada por la colaboración de Newton Freitas ${ }^{41}$, como se ve en las contraportadas de los números 1 y 2 . En el número 3, de 1943, Newton Freitas adquiere mayor relieve, pues aparece en la portada, en la contraportada y en la sección Notas con una reseña de su compatriota Jorge de Lima, Calunga ${ }^{42}$. En el número 4, desaparece el brasileño de la portada pero se mantiene en el Sumario y en Notas con una información sobre la colección que dirigen sus amigos Baudizzone y Seoane ${ }^{43}$. También esta presencia de Brasil se ve reforzada por la inclusión de la publicidad de la Editoria Nova de Don Casmurro de Machado de Assis, en los números 1 (pág. 57), 3 (pág. 59) y 4 (pág. 51). Javier Farías hace una reseña de Carybé ${ }^{44}$ en el número 6; y, por último Jorge Bogliano, en el número 7, también reseña El conventillo de Aluizio de Azevedo, con prólogo de Newton Freitas. Como curiosidad se puede citar el anuncio de una compañía brasileña que ofrece contactos con sus homólogas argentinas, en los números 1 (pág. 58) y 2 (pág. 56).

\section{El Correo Literario (1943-1945)}

Desaparecida De Mar a Mar, Lorenzo Varela, en 1943, funda, y codirige con L. Seoane y A. Cuadrado la revista Correo Literario ${ }^{45}$ (1943-1945) hasta que la revista muere «abatida por el peso político» y por problemas económicos,

${ }^{41}$ Algunos autores incluyen también entre los intelectuales brasileños a González Carbalho (F. Salgado, 2005a: 188). Según mis informaciones era de origen gallego-argentino

42 «Jorge de Lima y 'Calunga'»: 54-55.

${ }^{43}$ N. ${ }^{\circ} 4: 41-43$.

${ }^{44}$ Héctor Julio Paride Bernabó, Carybé (1911-1997), nacido en Lanús (Buenos Aires, Argentina) pero nacionalizado brasileño, autor de una amplia obra con una fuerte inspiración en la cultura afrobrasileña, hizo ilustraciones, por ejemplo, para libros de Mário de Andrade, García Márquez o Jorge Amado.

${ }^{45}$ Para Bilbao (2005) una de las mejores de su tiempo en América; para Salgado (ed.) (2005) la mejor revista del exilio. 
después de 40 números. El propósito de sus fundadores seguía de cerca el de las anteriores Romance y De Mar a Mar; es decir, ser 'un periódico para la mayoría, al servicio de la cultura hispanoamericana, difundiendo sus valores en cuanto esté al alcance de sus posibilidades' (F. Salgado, 2005a: 208), Aunque en sus palabras programáticas el Correo Literario se propone no ser un periódico político, de hecho, sus colaboraciones, aunque esencialmente literarias, representan un pluralismo estético e ideológico, y muestran una tendencia acorde con el izquierdismo de sus directores, en palabras de Alonso Montero (1995: 9). Por ello sus páginas aparecerán intelectuales, artistas y escritores, de América del Sur, de habla española y de habla portuguesa, además de gallegos, castellanos y brasileños: Alberti, Dieste, Gil-Albert, Mário de Andrade, Octavio Paz, entre otros muchos. La investigadora, M. ${ }^{a}$ Antonia Pérez Rodríguez (2005: 87-88), refiere que aunque Brasil era un país muy amado por Lorenzo Varela, la revista refleja pocas noticias a ese respecto. Reflexión ésta que una lectura más detallada conduce a rectificar. Antes de nada hay que mencionar una novedad y es que habrá en el Correo Literario una columna fija escrita en portugués. Es la primera vez que una revista, en las que haya tenido responsabilidad editorial L. Varela, tenga una sección, «Colaboración en portugués», casi siempre en esta lengua. De este apartado va a ser responsable Newton Freitas — cuya foto vemos en las portadas del número 18 (1944) y del 26-, hasta su marcha a París en 1945. Así pues el brasileño irá firmando textos de varia orden: crítica de cine ${ }^{46}$ (en realidad, una defensa de los símbolos y costumbres americanos frente a los europeos); la adaptación de los emigrantes ${ }^{47}$ a su nuevo hogar; las desavenencias con los intelectuales «cargosos» ${ }^{48}$; de contenido social ${ }^{49}$; la liberación de Francia ${ }^{50}$.

N. Freitas es también un redactor más de la revista que escribe sobre asuntos de actualidad: los actos que han tenido lugar en la librería y galería «Sagitario» de Buenos Aires ${ }^{51}$; sobre la poeta uruguaya Orfila Bardesio ${ }^{52}$; hace un repaso del «Ano literario argentino» ${ }^{53}$; habla sobre el pintor francés Gilles de Latourette y sobre algún personaje rioplatense (el banquero René Berger) ${ }^{54}$; el novelista argentino Enrique Amorim ${ }^{55}$; o la escultora M. ${ }^{a}$ Carmen Portela ${ }^{56}$. No están tampoco ausentes sus comentarios sobre autores españoles como la reseña que hace a Francisco de Ayala de su libro Histrionismo y representación ${ }^{57}$. Su pluma, a veces, se centra en asuntos gallegos: escribe sobre Castelao ${ }^{58}$; hace una re-

7.

46 «Cantinflas faz graça americana». Año I, n. ${ }^{\circ} 1,1943:$ 7. «Fragmentos». Año II, n. ${ }^{\circ} 25,1944$ :

47 «Preconceito ou Necessidade ?». Año II, n. ${ }^{\circ}$ 5, 15-I-1944: 7.

48 «Em defeza dos 'Cargosos'». Año II, n. ${ }^{\circ} 12,1944: 7$.

49 «Conceitos de Civilisação». Año II, n. ${ }^{\circ}$ 20, 1944: 7.

50 «França-França Libertada». Año II, n. ${ }^{\circ}$ 21, 1944: 7. «Ainda París». Año II, n. ${ }^{\circ} 22,1944: 7$.

${ }^{51}$ «Uma exposição e um Concerto». Ano I, n. ${ }^{\circ}$ 3, 1943: 7.

52 «Carrasco». Año II, n. ${ }^{\circ}$ 4, 1944: 7.

3 Año II, n. ${ }^{\circ}$ 6, 1944: 7.

54 «Dois Franceses no Rio da Prata». Año II, n. ${ }^{\circ}$ 7, 1944: 7.

55 «O ciclo novelista de Enrique Amorim». Año II, n. ${ }^{\circ} 23,1944: 7$.

«Fragmentos». Año II, n. ${ }^{\circ} 25,1944: 7$.

57 «Castagnino». Año II, n. ${ }^{\circ} 14,1944: 6$.

58 «Visitando Castelao». Año II, n. ${ }^{\circ} 13,1944: 7$. 
seña a Historias e Invenciones de Félix Muriel de Rafael Dieste ${ }^{59}$; habla sobre el libro de Seoane, Homenaje a la Torre de Hércules ${ }^{60}$; y parece que conoce la obra de Rosalía de Castro. Veamos estas líneas de 1989: «Dizem os galegos que quase todas as trovas ditas populares que correm as campinas da 'terriña' não têm origem popular, mas, ao contrário, nasceram da inspiração de Rosalía de Castro» (apud Silva, 1989: 153). La creación propia de Newton Freitas surge también en la Revista: su Prefacio ${ }^{61}$ a un libro de Luís Felipe de Melo; «Se fosse possível matar o tempo....» $»^{62}$; un fragmento de Viagem ${ }^{63} ;$ «Un caso sentimental» $»^{64} ;$ «João Experto ou o Reino das Tres Princesas» ${ }^{65}$. Pero Newton Freitas escribe sobre todo de asuntos brasileños que él conoce bien: el científico Carlos Chagas ${ }^{66}$; la esclavitud $^{67}$; la pintura ${ }^{68}$; la música ${ }^{69}$. Y la literatura. En este sentido refiere, con la excusa de una reseña a Nicolás Guillén, a Mário de Andrade y a Jorge de Lima $^{70}$; con motivo de la representación de Bodas de sangre ${ }^{71}$ hace un repaso al teatro de Brasil; da cuenta de un congreso de escritores brasileños y de su importancia en el cambio político; comenta Fogo morto de José Lins do Rego ${ }^{72}$; escribe sobre la poeta «Cecília Meirelles», que acaba de traducir Bodas de sangre $^{73}$; también sobre Afonso Arinos de Mello Franco ${ }^{74}$, Amando Fontes ${ }^{75}$, Graciliano Ramos, Alencar, Machado de Assis, Graça Aranha, José de Alequer, Raul Pompeia, Aluizio de Azevedo, Lima Barreto ${ }^{76}$. Pero la contribución cuantitativamente más importante es la Antología de la literatura brasileña que, a toda página, está en el mismo número 31 del Correo Literario ${ }^{77}$. Número que será el fin de la colaboración del brasileño ${ }^{78}$.

Newton Freitas es también sujeto de reseñas, comentarios y análisis de sus obras por parte de sus compatriotas y de sus amigos gallegos. Por ejemplo, L. S.

59 Año II, n. ${ }^{\circ}$ 6, 1944: 7.

${ }^{60}$ Año II, n. ${ }^{\circ} 14,1944: 7$.

${ }^{61}$ Año II, n. ${ }^{\circ} 11,1944: 7$.

62 Año II, n. ${ }^{\circ} 15,1944:$ 7-8.

63 Año II, n. ${ }^{\circ} 17,1944: 7$.

${ }^{64}$ Año II, n. ${ }^{\circ} 18:$ 7; y Año II, no 19 , 1944: 7-8.

${ }^{65}$ Año III, n. ${ }^{\circ} 28,1945: 7$.

${ }^{66}$ Año II, n. ${ }^{\circ} 27,1944: 7$.

67 «Palmarés, República Negra do Brasil». Año III, n. ${ }^{\circ}$ 29, 1945: 7; y Año III, n. ${ }^{\circ}$ 30, $1945: 7$.

68 «O Pintor Di Cavalcanti». Año I, n. ${ }^{\circ} 2$,1943: 7. «Noemia y su pintura». Año II, n. ${ }^{\circ} 13$, 1944: 5. «Os croquis do Pintor Portinari». Año II, n. ${ }^{\circ} 23$, 1944: 7. «Carlos Chagas». Año II, n. ${ }^{\circ} 27$, 1944: 7.

${ }^{69}$ «Villa Lobos y la evolución musical brasileña». Año II, n. ${ }^{\circ} 17$, n. ${ }^{\circ} 17,1944: 8$.

70 Año II, n. ${ }^{\circ} 8,1944:$ 7. Refiere la muerte de Mário de Andrade en «Carta abierta». Año III, n. ${ }^{\circ} 31,1945: 2$.

71 «O teatro brasileiro e García Lorca». Año II, n. ${ }^{\circ}$ 9, 1944: 7.

72 Año II, n. ${ }^{\circ}$ 14, 1944: 7.

Año II, n. ${ }^{\circ} 16,1944: 7$.

74 Año II, no 24, 1944: 7.

75 «Carlos Chagas». Año II, n. ${ }^{\circ} 27,1944: 7$.

${ }^{76}$ Año III, n. ${ }^{\circ}$ 31, 1945: 7.

77 «Poética brasileira». Año III, n. ${ }^{\text {o } 31,1945: 3 .}$

${ }^{78}$ «Nuevas». Año III, n. ${ }^{\circ}$ 32, 1945: 1. Donde se anuncia también la muerte de Mário de Andrade. 
(Luís Seoane) firma la reseña de Cantos y leyendas brasileñas, obra traducida, como ya se dijo, por Lorenzo Varela ${ }^{79}$; en la misma página 6, se anuncia Amazonia, reunión de mitos y leyendas, recogidos, como ya se vio, por N. Freitas y traducidos por Luis M. Buadizzone, con dibujos de Carybé ${ }^{80}$. Mário de Andrade hace una crítica al autor y a la obra de Ensayos americanos ${ }^{81}$. Su monografía $O$ Aleijadinho ${ }^{82}$ se anuncia en la Editorial Nova y Raúl Navarro hace la reseña ${ }^{83}$. Lorenzo Varela además escribe en «Premáticas y desahogos», en tono de humor, una recomendación al brasileño para que no organice el banquete de los intelectuales conocidos como los 'cargosos', por los problemas que de ahí le puedan venir ${ }^{84}$.

Sin duda el autor brasileño que más veces es referido, después de Newton Freitas, como sujeto activo o pasivo, es Mário de Andrade. Además del texto ya mencionado, dedicado a N. Freitas, encontramos el Prólogo que el autor había hecho para el álbum de dibujos de Lasar Segall ${ }^{85}$ y una columna sobre su compatriota «El pintor Clovis Graciano» ${ }^{86}$. A su muerte la revista le dedica varios homenajes a lo largo de tres números ${ }^{87}$ donde intervienen, entre otros, Vinicius de Moraes, Sérgio Milliet, Drummond de Andrade, ${ }^{88}$ o Tristão de Athayde ${ }^{89}$. Jorge Amado es asimismo uno de los escritores más referenciados en Correo Literario, como también lo fue en De Mar a Mar. Se informa de su produccción. Por ejemplo, que ha escrito un nuevo capítulo de El caballero de la esperanz $a^{90}$; y se anuncia la publicación de A vida de Luis Carlos Prestes ${ }^{91}$. Otros brasileños aparecen como colaboradores. Así Sérgio Milliet ${ }^{92}$, Graciliano Ramos ${ }^{93}$, Lúcia Miguel Pereira ${ }^{94}$, José Lins de Rego ${ }^{95}$, Alfonso Arinos de Melo Franco ${ }^{96}$ y, en los últimos números, Hildon Rocha ${ }^{97}$. Se dan noticias

79 Año I, n. ${ }^{\circ}$ 3, 1943: 6.

80 Año I, n. ${ }^{\circ}$ 3, 1943: 6. También se anuncia la Editorial Nova: Año, II, n. ${ }^{\text {4, } 1944: ~ 8 ; ~ y ~ e n ~}$ Año II, n. ${ }^{\circ}$ 6, 1944: 6 .

81 «Newton Freitas». Año II, n. ${ }^{\circ}$ 6, 1944: 1.

82 Año II, n. ${ }^{\circ}$ 17, 1944: 7. Año II, n. ${ }^{\circ}$ 18, 1944: 6. Año II, n. ${ }^{o}$ 19, 1944: 6. Año II, n. ${ }^{\circ} 21,1944$. Año II, n. ${ }^{\circ} 27,1944:$ 6. Año III, n. ${ }^{\circ}$ 28, 1945: 6; y Año III, n. ${ }^{\circ}$ 29, 1944: 7. Esta editorial aparece anunciada con frecuencia a lo largo de la colección.

83

84 Año, II, n. ${ }^{\circ} 11,1944: 2$.

85 Año II, n. ${ }^{\circ} 14,1944: 5$.

86 Año II, n. ${ }^{\circ} 25,1944: 5$.

87 Sin firma «La última entrevista de Mário Andrade». Año III, n. ${ }^{\circ}$ 32, 1945: 2.

88 «Homenaje a Mário de Andrade». Año III, n. ${ }^{\circ}$ 36, 1945: 3, 4 y 7.

89 «Mário de Andrade». Año III, n. ${ }^{\circ} 38,1945$ : 2; y «Notícias de Brasil» recoge el título en la misma página.

90 «Nuevas». Año III, n. ${ }^{\circ} 33,1945: 1$

91 «oticias de Brasil». Año III, n. ${ }^{\circ} 38,1945: 2$.

92 «Emiliano di Cavalcanti». Año II, n. ${ }^{\circ} 8,1944: 5$.

93 «Un nuevo profesor. Año II, n. ${ }^{\circ} 21,1944: 3$.

94 «Infancia». Año III, n. ${ }^{\circ}$ 33, 1945: 4.

95 «El maestro argentino». Año III, n. ${ }^{\circ} 34-35,1945: 4$.

${ }^{96}$ «Sur (El medio intelectual argentino (1)». Año III, n. ${ }^{\circ} 39,1945: 1$.

97 «O cinquentenario de Jorge de Lima». Año III, n. ${ }^{\circ}$ 39, 1945: 2. «Panorama literario». Año III, n. ${ }^{\circ} 40,1945: 7$ con informaciones de otros escritores brasileños. 
también sobre Rubem Braga, Manoel Bandeira, Álvaro Lins, Jorge Lima ${ }^{98}$ y José Lins do Rego ${ }^{99}$. Se anuncia que está a la venta Don Casmurro de Machado de Assís ${ }^{100}$, Dom Pedro I de Brasil ${ }^{101}$, Caminos cruzados de Erico Veríssimo $^{102}$, Brasil de Luis Felipe de Melo ${ }^{103}$, y las recientes publicaciones de Carlos Drumond de Andrade, Mário de Andrade o Vinicius de Moraes ${ }^{104}$. Se hacen reseñas de arte, literatura y política de autores brasileños. Por ejemplo, de Reinaldo Moura, Mar do tempo ${ }^{105}$; de Ana Amélia Carneiro de Mendonça ${ }^{106}$, Dois meses entre os americanos; de Moysés Vellinho, Letras da Província ${ }^{107}$; de Marques Rebelo Vida e obra de Manuel Antonio de Almeida ${ }^{108}$; de Graciliano Ramos Angustia ${ }^{109}$. La presencia femenina brasileña en el Correo Literario viene de la mano de Lídia Besouchet. Lídia Besouchet de Freitas (Porto Alegre, 23 mayo 1908 - Río de Janeiro 1997) trabajó los más variados géneros literarios pues fue desde novelista a biógrafa, cuentista, crítica literaria e historiadora. Por haber participado activamente en las campañas revolucionarias brasileñas, se vio obligada a exiliarse, en 1937, primero a Uruguay y después a Argentina, donde permaneció durante diez años y donde se casó con Newton Freitas. En Buenos Aires publicó en periódicos y revistas y trabajó como funcionaria del Escritório Comercial de Brasil. Su casa fue un lugar de encuentro para los intelectuales en las varias ciudades en las que vivió ${ }^{110}$. La mujer aparece como autora, por ejemplo, de un artículo sobre cómo se ven los brasileños y cómo han sido vistos por María Rosa Oliver. La escritora aprovecha la oportunidad para referir a algunos compatriotas escritores: Mário de Andrade, Graciliano Ramos, Cecília Meireles, Machado de Assis, Vinicius de Morais; y ar$\operatorname{tistas}^{111}$. La revista incluye una bella foto de la mujer con motivo de anunciar la publicación de su libro José Maria Paranhos, Vizconde do Rio Branco ${ }^{112}$, que más adelante aparece reseñado ${ }^{113}$. Y después se da cuenta en la portada, de nuevo con su foto, de Condición de mujer ${ }^{114}$.

98 Año III, n. ${ }^{\circ} 39$, 1945: 2.

99 «Nuevas». Año III, n. ${ }^{\circ}$ 36, 1945: 1.

100 Año II, n. ${ }^{\circ}$ 6, 1944: 6.

101 Año II, n. ${ }^{\circ} 9,1944: 6$.

102 «Libros del mes». Año III, n. ${ }^{\circ} 32,1945: 7$.

${ }^{103}$ Año II, n. ${ }^{\circ}$ 24, 1944: 7.

104 «Noticias de Brasil». Año III, n. ${ }^{\circ}$ 38, 1945: 2.

105 Año II, n. ${ }^{\circ}$ 20, 1944: 6.

106 Año II, n. ${ }^{\circ} 23,1944: 7$.

107 Año III, n. ${ }^{\circ} 28,1945: 6$.

108 Año III, n. ${ }^{\circ} 29,15-\mathrm{I}-1945: 7$.

109 Año III, n. ${ }^{\circ} 34-35,1945: 6$.

110 Algunos títulos: (1940): Mauá y su época. Buenos Aires: Americana. Hay texto en port., 1942, Mauá e seu tempo. São Paulo: Anchieta. (1941): Desarrollo industrial del Brasil. Buenos Aires [s.n.]. et alii (1942): Un novelista argentino. Buenos Aires. (1943): Correspondência política de Mauá no Rio da Prata. São Paulo. Editora Nacional. Prefacio y notas de Lídia Besouchet.

111 «El Brasil de María Rosa Oliver». Año II, n. ${ }^{\circ}$ 9, 1944: 3 y 7.

112 Año III, n. ${ }^{\circ} 30,1945: 1$.

113 «Una biografía brasileña». Año III, n. ${ }^{\circ} 32,1945: 6$.

114 Año III, n. ${ }^{\circ}$ 39, 1945: 1. 
Es en esta primera etapa de su exilio argentino, en 1944, cuando Lorenzo Varela escribe en gallego ${ }^{115}$ Catro poemas pra catro grabados para el álbum de Luís Seoane María Pita e tres retratos medievais (Bernárdez, 2005: 54-56). El escritor pertenece a la generación de $1936^{116}$, a un grupo de intelectuales ${ }^{117}$ que en el exilio continúan el espíritu universitario izquierdista de los años de la República, puente entre la literatura ${ }^{118}$ de preguerra y de las nuevas promociones, en palabras de López Bernárdez (1999: 29).

\section{Cabalgata (1946-1948)}

Otra tentativa de nuestro autor de reunir el mundo americano, español y portugués de Brasil, se refleja en los objetivos de una nueva revista Cabalgata. Quincenario Popular (1946-1948), que dirigirán L. Varela y L. Seoane (F. Salgado, 2005a: 115), con un formato semejante a Correo Literario. Abarca su distribución a varios países latinoamericanos, entre ellos, en menor medida, a Brasil (Pérez Rodríguez, 2005: 100). No ha sido posible consultar esta revista pero X. L. Axeitos (2003: 168-173), que comenta el contenido del número 0, 1 y 2, no menciona ninguna contribución hacia las artes y literatura brasileña, aunque ello no quiere decir que no exista, además porque como dice Andújar (1976: 82) entre la lista de sus colaboradores está Newton Freitas.

\subsection{El exilio en Uruguay (1947-1952)}

Problemas políticos, por ejemplo la subida al poder de Perón, habían obligado en 1946 al cierre de la revista Cabalgata (Bernárdez, 2005: 49-52). Nuestro autor se ve impelido, una vez más, a emigrar ahora a Uruguay. Así a partir de 1947 va a vivir durante cuatro años (D. Salgado, 2005: 154, n. 26) en Montevideo. Allí se mueve alrededor de la librería de Élida Core, se defiende dando clases de español, dicta alguna conferencia y colabora con la editorial Pueblos Unidos y con la galería Arte Bella (Ferreiro Fente, 2005: 82 y F. Salgado, 2005a: 254). Pero los vínculos con el mundo cultural brasileño se mantienen mientras permanece en Montevideo. Además de hacer traducciones de portugués, sabemos que está al tanto por carta enviada, en 1947, por Luís Seoane, donde éste comenta a Lorenzo Varela, las actividades referentes a Carybé y al pintor y muralista brasileño Cándido Portinari. Un tiempo después, en 1951, el mismo L. Seoane refiere a L. Varela la edición de un libro de una amiga brasileña, tal vez Lídia Besouchet: «A Élida le escribiré uno de estos días. Adelántale que el libro de nuestra amiga brasileña, está haciéndose siguiendo todas las indicaciones vuestras y que quedará muy bien» (apud Axeitos, 2005: 36-37).

115 Cfr. F. Salgado (2005a: 235), Blanco (2005: 40-44) o García López (2005a).

116 Cfr. Aznar Soler (ed.) (1995).

117 Otros compañeros de generación pueden ser Aquilino Iglesia Alvariño, Xosé María Álvarez Blázquez o Xosé María Díaz Castro (Quintá, 2005ª 31).

118 Estudios sobre la obra en Insua (2005), Axeitos (2005), Albornoz (1976) o Quintá (2005ª). 


\subsection{El regreso de nuevo a Argentina (1952-1976)}

En marzo de 1952 L. Varela está de nuevo en Buenos Aires donde va a seguir combinando las actividades periodísticas, críticas y literarias. En lo que se refiere a la creación, publicará, en 1954, su último libro de poemas en gallego, Lon$x e^{119}$. A partir de entonces su actividad literaria será cada vez más esporádica, pues L. Varela se dedicará, esencialmente, al periodismo escrito y radiofónico. Durante este tiempo también dictará conferencias sobre arte ${ }^{120}$ y literatura en diversos foros latinoamericanos, por ejemplo, en 1962, en el Museo de Arte Moderno de Río de Janeiro; presentará exposiciones, organizará recitales de poesía y hará traducciones de inglés, francés y portugués de Jorge Amado (Dona Flor e seus dois maridos ${ }^{121}$ y Tenda dos milagres ${ }^{122}$ ). En 1960 se casará con Marika Gerstein (1906-1992) ${ }^{123}$, que será su compañera hasta el último día de Lorenzo Varela, esposa que acabará por fallecer en Las Palmas (Ferreiro Fente (2003:191).

\section{EL REGRESO A ESPAÑA (1976-1979)}

A principios de los años setenta nuestro escritor decide regressar a España. La subida al poder de Videla, en 1976, le empujan a tomar la decisión final de regresar (F. Salgado, 2005a: 313). Sale por la frontera de Brasil donde permanece una temporada hasta trasladarse a España. Va a vivir esos dos últimos años y medio a caballo entre Madrid y Galicia. En Madrid, primero en la calle Ponzano, en el piso de Isaac Díaz Pardo (Louzao Outeiro (2007: 186). Después, en 1978, cuando viene su mujer, van a vivir a la calle Almagro, donde fallecerá (Ferreiro Fente, 1992: 550, n. 31). Newton Freitas está en funciones diplomáticas en Madrid en la embajada de Brasil en el momento del regreso de L. Varela a España, pues en la Revista de Cultura Brasileña, que editaba la Embajada de Brasil en España, con fecha de mayo de 1971, hay una colaboración del mismo lo que probablemente indica que entonces ya se encontraba en Madrid. Por el testimonio de Inés Canosa sabemos que la amistad había continuado entre ambos: «Outro grande amigo del, que pasaba tódalas mañáns a preguntarme por él, era o escritor brasileiro N. Freitas. El traballaba na Ambaixada, dicíame que quería acompañalo, estar con él ... é dicir, que sentía a súa presenza e a súa solidariedade» (Mejía Ruiz, 2005: 123).

119 Más información sobre el contenido del libro en F. Salgado (2005a: 113).

${ }^{120}$ Uno de los asuntos que más le entusiasmaron fue la crítica de arte. Los últimos decenios de su vida en Argentina los dedicó a esta actividad. En ese sentido hará cientos de reseñas y varias monografías sobre el hecho artístico, por ejemplo, sobre un tema brasileño, 'Para unas fotografías de Horacio Cóppola sobre la obra de 'O Aleijadinho', publicado en 1955, en Buenos Aires (F. Salgado, 2005a: 293 y ss.).

${ }^{121}$ Existen varias reediciones, por ejemplo, de 1981 y de 1985 en Madrid: Alianza; o de 1993 en Barcelona: RBA.

${ }^{122}$ Hay varias reediciones, por ejemplo, de 1971 y de 1972. Según Pérez Rodríguez (2005: 15) hizo muchísimas traducciones de portugués y de francés casi todas sin firmar.

${ }^{123}$ Un hijo de Marika, Ariel, recuerda que Lorenzo Varela había aparecido por la casa entre 1945 y 1947 (Salgado, 2005: 115). De hecho hay cartas anteriores, de entre los años 50 y 51, dirigidas por el escritor a Marika (Salgado, 2005ª 31 ). 
El matrimonio le convidaba a su casa y él iba con frecuencia. Eran muy atentos con él y se notaba que tenían ganas de acompañarle. Newton me pedía que le pusiese en el espejo del baño una nota diciéndole que había pasado a verle. Pero Lorenzo Varela no contestaba y Newton se notaba que se quedada desconsolado. El brasileño se daba cuenta de lo que estaba pasando, que Lorenzo Varela desaparecía y se aislaba. Así que dejó de venir. Pero estuvo en el entierro de Varela en la Almudena ${ }^{124}$ (Informaciones recogidas en una entrevista personal en julio de 2006).

En la galería Sargadelos de Madrid seguía su vínculo con la producción brasileña: traducía todos los días Os Sertões de Euclides da Cunha, según un encargo del crítico literario, Ángel Rama, para la editorial Ayacucho (Salgado (ed.), 2005: 85). Inés Canosa nos habla de la traducción que L. Varela tenía entre manos: «Se instalara nun 'despachito' da Galería Sargadelos, onde se ocupaba polas tardes da tradución de Os Sertões, de Euclides da Cunha» (Mejía Ruiz, 2005: 169-170). Pero L. Varela se queja, en carta de 1976, a los Seoane de esta tarea: «Sigo con la difícil e interminable traducción de Os Sertões, que me maniata para muchas cosas, pues no me deja tiempo ni energía para nada. (Ahora estuve descansando unos días en el Castro, sin hacer nada (...), pero ya comienzo mañana a traducir nuevamente» (apud Salgado (ed.), 2005: 92). Y este malestar que sentía se resuelve en el abandono de la traducción, como se ve en la carta que dirige al propio Ángel Rama:

Confío haya quedado claro que entre las opciones que usted comprensiva y generosamente me daba, yo elegía la de renunciar a seguir por ahora la traducción de Os Sertões. Lo he meditado bien y he tomado esa resolución, que sin duda no es la que usted merece ... ni yo tampoco. (...) Adiós, pues, a Os Sertões, con renovadas peticiones de perdón. Espero tener 'vacíos' para terminarla (tengo 380 páginas en bastante buen estado) y ofrecerla a 'Ayacucho' para una edición futura o a alguna editorial española (idem).

Hasta sus últimos días (murió el 25 de noviembre de 1978 en Madrid, a los 61 años de edad) el mundo cultural brasileño estuvo presente en la imagen de Lorenzo Varela. Decide en una ensoñación marcharse a París, y vivir haciendo traducciones de libros brasileños. Las últimas referencias que poseemos hasta la fecha, por orden cronológico, sobre las relaciones que mantuvo con la cultura brasileña vienen a través del texto que hizo para el catálogo de la exposición sobre Brasil del fotógrafo gallego José Suárez, que se presentó en la Casa do Brasil en 1977 (Axeitos, 2001: 161, n. 23). El Prólogo que escribió para el libro de Valentín Paz-Andrade, en 1978, A galecidade na obra de Guimarães Rosa, curiosamente con una introducción en portugués (págs. 5-7) del brasileño Raulo Ronai, a la que L. Varela hace referencia citando largos párrafos; y la reseña sobre este mismo texto, «Guimarães Rosa y Galicia», publicada en El País, el 28 de enero de 1979 (F. Salgado, 2005a: 126). Además, por último, el conocimiento que L. Varela tiene del mundo portugués se ve re-

${ }^{124}$ Probablemente los Freitas se fueron de Madrid entre el 79 y 80. 
flejado en una carta que le envía Carlos Gurméndez para solicitarle información sobre obras de literatura 'hispano-luso-americana' porque tiene puestos de responsabilidad en Madrid algunas editoriales (F. Salgado, 2005a: 305, n. 18). Dice Lídia Besouchet, en 1979, en un texto inteligente, «O mistério Lorenzo Varela», donde la autora parece tener un concienzudo conocimiento del autor y de la obra del que homenajea, que L. Varela es un misterio pero ante todo es un poeta:

Só existe uma palavra apropriada para definir o poeta galego (...): mistério. Aceitando a palavra mistério como o culto do hermetismo, como uma secreta reserva do ser, como a ocultação enigmática para exprimir-se à maneira dos autos medievais, a inexplicável personalidade poética de Varela não se enquadra senão dentro da palavra mistério (pág. 17).

Por la escritora sabemos que había pronunciado, en 1962, la conferencia ya referida sobre Juan Gris en el Museo de Arte Moderno de Río de Janeiro en la que éste defendió la idea de que el pintor había vivido su vida 'viviéndola en poeta'. Pero la autora intuye que nuestro escritor estaba hablando de él mismo, de su vida en poeta ${ }^{125}$, no de la del pintor español: «Foi um poeta em busca da infância perdida numa terra húmida e verde, com vigor do paraíso e tendendo sempre à universalização através de dois idiomas que lhe eram afins, mas que não lhe foram 'familiares' no sentido mais estrito da palabra» (Besouchet, 1979: 20). La escritora brasileña estará en antologías, homenajes y otras publicaciones que recuerdan a L. Varela. Por ejemplo, en el volumen que preparó Xesús Alonso Montero, Dez poemas en 1988. La presencia de la pareja BesouchetFreitas surge por primera vez en la vida de Lorenzo Varela, que sepamos, en los años cuarenta y vuelve a reaparecer en los años setenta en Madrid, últimos de vida del autor. X. L. Axeitos (2003: 291) recoge una sentida carta que envió N. Freitas, inmediatamente después del fallecimiento de L. Varela, a Baudi[zzone], otro compañero de la etapa bonaerense ${ }^{126}$. Esa carta transmite la fluida amistad que había existido entre ambos:

Tive nesse tempo que ele passou em Madrid várias conversas com ele. Eram conversas gerais porque o Lorenzo não intimava com ninguém. (...) Às vezes referia-se (várias vezes notei em jantares aqui em casa) com saudade de você, do Seoane, do Cuadrado e também dos nossos tempos de B. Aires, cheios de esperanças, de ilusões (pág. 291).

Fechado a todos, mesmo aos mais íntimos, prevaleceu nele o pudor de revelar o talento que possuia. Como se se envergonhasse da inteligência que o povoava, como se estivesse invadido pelo temor de ser enfrentado, comparado, equiparado, classificado entre as múltiplas revelações intelectuais das pequenas glórias que via girar em torno, preocupadas apenas em persistir no Tempo que

${ }^{125}$ La misma idea de que Lorenzo Varela es esencialmente poeta la comparte, por ejemplo, Axeitos (2001: 9).

${ }^{126}$ Luis M. Baudizzone era abogado bonaerense con quien compartieron charlas y editoriales Varela y Freitas. 
passa ... O pudor de ser realmente o que era —Poeta, foi o maior afá de sua vida (pág. 17).

Desde el otro lado, el conocimiento del mundo gallego por parte de Newton Freitas debe haber continuado a largo del tiempo como lo demuestra la forma en que se refiere a muchos de los escritores, en la carta ya citada que dirige a Baudizzone: «Já estão aquí os Dieste, os Pardos (...). O Laxeiro depois de prestar seus bons ofícios, viajou para Galícia (...). Acabo de receber um telefonema do Paz Andrade». La primera mención que encontramos de L. Varela sobre los Newton es una carta dirigida a su mujer, desde Madrid en 1977. El tono de la misma indica que el matrimonio brasileño era una referencia cotidiana para la pareja:

Los Newton y los Suárez, muy contentos con mi prólogo y con el Bergamín. Pero los Newton mucho más contentos con mi idea de presentar la traducción al portugués de Tirano Banderas - que ya me hizo llegar y que en principio parece muy buena - en Galicia. Más les va a alegrar, todavía, mi sugerencia de que se haga lo mismo en Lisboa y en Madrid (Salgado (ed.), 2005: 96).

De L. Varela, dice M. ${ }^{a}$ Antonia Pérez Rodríguez (2005: 131 y 133) que hay muchas colaboraciones repartidas en publicaciones mejicanas, argentinas y uruguayas, además de aquellas otras que no llevaron su firma para mantener el anonimato política y socialmente deseado. Se podría rastrear, así, su etapa en Montevideo, en el círculo de la librería de Élida Core y de la galería Arte Bella, en los periódicos mejicanos (Salgado et alii, 2005: 20); aquéllos en los que colaboró durante su estancia en Buenos Aires, y las revistas, además de los programas radiofónicos y de televisión en los que participó, para obtener una imagen completa de su vínculo con las artes y las letras brasileñas. De este modo, probablemente, según se vayan conociendo las correspondencias de los amigos con los que L. Varela intercambió cartas, así como las revistas y periódicos de Brasil de la época, irán fortaleciéndose la hipótesis que confirme su conocimiento de la cultura brasileña y la frecuente relación que el autor tuvo a lo largo de su vida con escritores y artistas de esa nacionalidad.

\section{BIBLIOGRAFÍA}

Albornoz, A. (1976): «Poesía de la España peregrina: crónica incompleta». In J. L. Abellán (dir.), El exilio español de 1939. Cultura y Literatura. Barcelona: Taurus, vol. IV: $11-108$.

AlCAlÁ, M. (1990): «Las vanguardias argentina y brasileña frente al espejo». Cuadernos Hispanoamericanos 480: 89-100.

Alonso Montero, X. (1976): Lingua e literatura galegas na Galicia emigrante. Santiago: Xunta de Galicia.

- (1977): «El poeta gallego Lorenzo Varela retorna del exilio». Triunfo 763, 10-091977. Madrid; reproducido en Madrygal 8, 2005: 128.

- (1994): As palabras no exilio. Vigo: Ediciós Xerais. 
- (1995): Lingua e literatura galegas na Galicia emigrante. Xunta de Galicia.

- (coord.) (2005): Días das letras galegas. Lorenzo Varela. 2005. Santiago de Compostela: Universidad de Santiago de Compostela.

Antelo, R. (ed.) (en prensa): Correspondência de Mário de Andrade e Newton Freitas. São Paulo: Edusp.

Álvarez, R y D. Vilavedra (eds.) (1999): Cinguidos por unha arela común. Homenaxe ó Profesor Xesús Alonso Montero. Santiago de Compostela: Universidad de Santiago de Compostela

ANDÚJAR, M. (1976): «Las revistas culturales y literarias del exilio en Hispanoamérica». In J. L. Abellán (dir.), El exilio español de 1939. Revistas, pensamiento, educación. Barcelona: Taurus, vol. III: 21-92.

Axeitos, X., L. (1999): «A revista Cabalgata, outra publicación do exilio galego». In R. Álvarez y D. Vilavedra (eds.) (1999), vol. II: 153-159.

- (2003): «A revista Cabalgata, outra publicación do exilio galego». In O exilio galego: un mapa de cicatrices. Sada - A Coruña: Ediciós do Castro: 15-174.

- (2003a): «Vida, paxón e morte de Lorenzo Varela». In O exilio galego: un mapa de cicatrices. Sada - A Coruña: Ediciós do Castro: 285-295.

- (2005): Algunhas reflexións sobre o exilio e Lorenzo Varela. A Coruña: Ediciós do Castro.

- (2005a): «Cinco cartas de Luís Seoane a Lorenzo Varela (1947-1951)». In X. Alonso Montero (coord.), Días das letras galegas. Lorenzo Varela. 2005. Santiago de Compostela: Universidad de Santiago de Compostela: 25-38.

Axeitos, X. L. (ed.) (2000): Lorenzo Varela: Poesía completa. A Coruña: Ediciós do Castro.

- (2001): Lorenzo Varela: Ensayos, conferencias y otros escritos. II. A Coruña: Ediciós do Castro.

Axeitos, X. L. y X. SEOANE (1994): «Luís Seoane e o libro galego na Arxentina (19371979)». In X. L. Axeitos (ed.) Luís Seoane e o libro galego na Arxentina [19371939]. A Coruña: Diputación de A Coruña: 6-24.

Aznar Soler, M. (ed.) (1995): Las literaturas exiliadas en 1939. Barcelona: Gexel.

BERNÁRDEZ, C. (2005): Lorenzo Varela: biografía e antoloxía. Vigo: Xerais.

Besouchet, L. (1979): «O mistério Lorenzo Varela». In Luís Seoane (ed.) Lorenzo Varela. Homaxes. A Coruña: Ediciós do Castro: 17-20.

- (1989): «Carybé». In B. Furrer, (ed.): Carybé. São Paulo: Odebrecht: 29-66.

Bilbao, C., S. Noia y A. Lopo (coords.) (2005): Trasterrados. Dicionario do exilio galego. Santiago de Compostela: Galicia Hoxe.

Blanco, C. (2005): «Ánxel Fole e Lorenzo Varela con Lugo ao fondo: o cervo ferido e o león». In X. Alonso Montero (coord.), Días das letras galegas. Lorenzo Varela. 2005. Santiago de Compostela: Universidad de Santiago de Compostela: 39-52.

CAllón Torres, C. (2005): Unha historia que nos pertence. A poesía en galego de Lorenzo Varela. Vigo: A Nosa Terra. 
CANOSA, I. (2005): Raigame 21: 31-32.

- Correo literario. Noviembre 1943-septiembre 1945. Directores: A. Cuadrado, L. Seoane y L. Varela. Facsímil. Sada — A Coruña: Ediciós do Castro, 1994. Prólogo: $\mathrm{X}$. Alonso Montero.

- De mar a mar. Revista literaria mensual. Diciembre 1942-junio 1943. Director: Lorenzo Varela. Facsímile. Madrid/Vaduz: Topos Verlag AG, 1979.

DíAz PARDo, I. (2005): Raigame 21: 33-37.

FerReiro Fente, X. G. (1992): «Once cartas a Lorenzo Varela: seis de Luís Seoane e cinco de Ernesto Sábato», Grial 116: 540-556.

- (1997): «Ánxel Fole e Lorenzo Varela: lembranzas dun tempo de ilusión». In X. Alonso Montero (ed.), Día das Letras Galegas. Ánxel Fole. 1997. Santiago de Compostela: Universidad de Santiago de Compostela: 81-88.

- (1999): «A poesía de guerra de Lorenzo Varela». In R. Álvarez y D. Vilavedra (eds.) (1999), vol. II: 529-554

- (2005): 'Diccionario' Lorenzo Varela. Santa Comba - A Coruña: TresCtres.

- (ed.) (2003): Homenaxe. Sesenta e seis escritores falan de Lorenzo Varela (florilexio de textos sobre a vida, a obra e o home). Sada-A Coruña: Ediciós do Castro.

FERRIZ, M. ${ }^{a}$ T. (1992): «La revisa literaria De Mar a Mar: la cultura española en la Argentina de los años cuarenta». Scriptura 8-9: 341-357.

Freitas, N. (1944): «Luis Reinaudi». Correo Literario, 26: 1.

— (1971): «Notas sobre el teatro en el Brasil». Revista de Cultura Brasileña 31: 97-100.

- (1979): «Réquiem para Luís Seoane». Revista de Cultura Brasileña 50: 97-98. Madrid.

FuRRER, B. (ed.) (1989): Carybé. São Paulo: Odebrecht.

GARCíA LóPEZ, X. A. (2005): «En lembranza dos irmáns: un poema e algúns datos de interese sobre os anos $\mathrm{e}$ as amizades lucenses de Lorenzo Varela», Dorna 30: 117-129.

- $\left(2005^{\mathrm{a}}\right)$ : «Poemas ignorados ou esquecidos de Lorenzo Varela». In Congreso sobre Varela. Santiago de Compostela: Xunta de Galicia: 195-239.

- (2009): De boa tinta. Repertorio bibliográfico de e sobre Lorenzo Varela. Vigo: Xerais.

GriLlo, M. ${ }^{a}$ R. (1996): «La literatura del exilio». In L. de Llera Esteban (coord.), El último exilio español en América. Madrid: MAPFRE: 317-497.

InSUA, E. X. (2005). «Curadas do exilio. II». Cerna 45: 46-49.

López BernárdeZ, X. C. (1999): «Introducción». In Lorenzo Varela, Poesía galega. Vigo: Xerais: 11-48.

- (2005): Lorenzo Varela. Vida e obra. Vigo: Xerais.

Lopo, A. (2005): As tres mortes de Lorenzo Varela. Vigo: Galaxia.

LouZAo Outeiro, M. (2005): «Entrevista. Isaac Díaz Pardo: «Nós non esquecemos nada». Madrygal 7: 181-187. 
Mejía Ruiz, C. (2005): «O soño de Lorenzo Varela». Madrygal 8: 123-129.

NeIRA VILAS, X. (2001): A cultura galega en Buenos Aires: 1950-1960. Discurso lido o día 17 de novembro de 2001 no Acto da súa recepción na Real Academia Galega. A Coruña.

Pérez Rodríguez, M. ${ }^{a}$ A. (2005): «Estudo introdutorio». In X. López García et alii (coords.), Lorenzo Varela en revistas culturais de México e Bos Aires. Santiago de Compostela: Consello da Cultura Galega: 13-135.

Quintá García, P. (2005): Lorenzo Varela. Santiago de Compostela: Xunta de Galicia.

- $\left(2005^{a}\right)$ : «Lorenzo Varela no contexto da poesía galega». In Congreso sobre Lorenzo Varela. Santiago de Compostela: Xunta de Galicia: 29-51.

RodríGUEZ FER, Cl. (1994): A literatura galega durante a guerra civil (1936-1939). Vigo: Xerais.

— (1999): «Escritos de combate de Lorenzo Varela». In R. Álvarez y D. Vilavedra (eds.) (1999), vol. II: 1321-1343.

- Romance. Revista Popular Hispanoamericana (1940-1941). México. Facsímile. 1974. Nendeln-Liechtenstein. Verlag Detlev Auvermann KG. Introd. de Antonio Sánchez-Barbudo.

SAlgado, D. (2005): «A poesía e o Correo literario. Aspectos». In X. Alonso Montero (coord.): 141-164.

- (2005a): «A fin da esperanza: Lorenzo Varela no Correo literario». In Congreso sobre Lorenzo Varela. Santiago de Compostela: Xunta de Galicia: 87-98.

- (1995): Lorenzo Varela: crónica dunha vida atormentada: A Coruña: Ediciós do Castro.

- (2005): Lorenzo Varela. Memorias incompletas. [A Coruña]: A Voz de Galicia.

- (2005a): Lorenzo Varela: A voz desterrada. Sada - A Coruña: Ediciós do Castro.

- (2005b): Lorenzo Varela: a voz desterrada. Sada - A Coruña: Ediciós do Castro.

- (ed.) (2005): Vinte e nove cartas de Lorenzo Varela. Sada-A Coruña: Ediciós do Castro.

SAlgado, F. et alii (2005): Lorenzo Varela (1916-1978). Unha fotobiografía Vigo: Xerais/Consello da Cultura Galega.

SÁnCHez BARbUdO, A. (1974): «Introducción». In Romance. Revista Popular.

SeOANE, L. (1979). «Lorenzo Varela», Grial 64: 232-236

- (ed.) (1979): Lorenzo Varela. Homaxes. A Coruña. Ediciós do Castro.

Silva, J. Claúdio da (1989): «As artes de Carybé». In B. Furrer (ed.) Carybé. São Paulo: Odebrecht: 140-166.

Soutelo VÁzquEz, R. (1998): «Memoria oral e identidade étnica da inmigración española a Latinoamérica no século XX: os galegos en Brasil, 1880-1970», Estudios migratorios 6: 99-124.

VARela, L. (1978): «Prólogo». In Paz — Andrade, V. Sada-A Coruña: Ediciós do Castro: $5-7$. 
- (1979): «Prólogo». In De Mar a Mar: V-IX.

- (1988): Dez poemas. Ed. estudio y notas de X. Alonso Montero. A Coruña: Ediciós do Castro. 